\title{
Community interventions and strategies for caries control in Latin American and Caribbean countries
}

\author{
Antônio Pedro RICOMINI \\ FILHO(a) $^{(i D}$ \\ Bertha Angélica CHÁVEZ(b) \\ Rodrigo Andrés GIACAMAN(c) \\ Paulo FRAZÃO(d) ${ }^{(1 D}$ \\ Jaime Aparecido CURY(a) \\ (a) Universidade de Campinas - Unicamp, \\ Piracicaba Dental School, Department of \\ Biosciences, Piracicaba, SP, Brazil. \\ (b) Peruvian Society of Pediatric Dentistry, \\ Lima, Peru. \\ (c) University of Talca - UTALCA, Faculty \\ of Health Sciences, Department of Oral \\ Rehabilitation, Cariology Unit, Talca, Chile. \\ (d) Universidade de São Paulo - USP, Public \\ Health School, São Paulo, SP, Brazil.
}

Declaration of Interests: The authors certify that they have no commercial or associative interest that represents a conflict of interest in connection with the manuscript.

Corresponding Author: Antônio Pedro Ricomini Filho E-mail: ricomini@unicamp.br

https://doi.org/10.1590/1807-3107bor-2021.vol35.0054

Submitted: March 10, 2021

Accepted for publication: March 11, 2021

Last revision: March 16, 2021
Abstract: Dental caries remains highly prevalent in Latin American and Caribbean countries (LACC). However, this disease can be controlled through interventions that implement evidence-based strategies in an affordable manner and that target all population groups instead of the most affluent only. Therefore, the aim of this report was to summarize the main scientifically documented community interventions and strategies based on restriction of sugars consumption, use of fluoride, and the use of occlusal sealants for caries control in LACC. A critical literature review was carried out in a systematic manner that included defined search strategies, independent review of the identified publications, and compilation of results in this report. Three systematic searches were conducted using the PubMed, LILACS, and SciELO databases to identify studies related to community interventions and strategies for caries control in LACC. Of the 37 publications identified, twenty-six focused on fluoride use, eight on occlusal sealant use, and three on the restriction of sugar consumption. Documented community interventions for sugars restriction were scarce in the region and were based on food supplementation, sugar replacement, and education. Thus, local and/or national policies should prioritize investment in upstream, coherent, and integrated population-wide policies such as taxes on sugary drinks and stronger regulation of advertising and promotion of sugary foods and drinks mainly targeting children. The main fluoride-based strategies used drinking water, refined domestic salt, cow milk, toothpaste and, to a lesser extent, mouth-rinses, acidulated phosphate fluoride (APF) gels, and varnishes to deliver fluoride to the population. Evidence of fluoride use was seen in Argentina, Belize, Bolivia, Brazil, Chile, Colombia, Costa Rica, Cuba, Dominican Republic, Ecuador, El Salvador, Guatemala, Haiti, Honduras, Mexico, Nicaragua, Panama, Paraguay, Peru, Uruguay, and Venezuela. Studies reporting the use of occlusal sealants were mainly located in Brazil, Chile, Colombia, Costa Rica, Peru, Mexico, and Venezuela. Community interventions restricting sugar consumption should be implemented at the individual level and through public policies. The use of fluoride must be monitored at the local, regional, and national levels so as to achieve maximum anti-caries effect while also minimizing the risk of dental fluorosis. Moreover, fluoridated water and salt programs, used as a mutually exclusive community level strategy for caries control, should expand their benefits to reach non-covered areas of the LACC 
while also simultaneously providing adequate surveillance of the fluoride concentration delivered to the population. Regulating the concentration of soluble fluoride (for anti-caries effect) in dentifrice formulations is also necessary in order to provide the population with an effective strategy for disease control. Targeting culturally appropriate, economically sustainable caries control interventions to rural populations and native ethnic groups such as indigenous people, quilombolas (African-origin), and riverside Amazonian people remains a crucial challenge.

Keywords: Dental Caries; Latin American; Caribbean Region; Sugars; Fluorides.

\section{Introduction}

Despite rapid advances in the understanding of dental caries and strategies to control it, ${ }^{1}$ the disease continues to be highly prevalent in many countries, particularly in Latin American and Caribbean countries (LACC). ${ }^{2,3}$ Dental caries occurs due to frequent exposure of the dental biofilm to sugars, highlighting the key role that dietary carbohydrates play in disease onset and progression. ${ }^{4,5}$ These sugars are fermented by bacteria present in the biofilm, producing acids that lead to tooth (enamel/dentine) demineralization via a physicochemical process. ${ }^{6}$ Consequently, teeth that are exposed to periods of demineralization more frequently than remineralization, which is a naturally occurring process, exhibit increased loss of tooth minerals and subsequent development of caries lesions. ${ }^{4}$

Sugars play a pivotal role in the development of dental caries as without fermentable carbohydrates, the bacteria are unable to produce acids necessary for tooth demineralization. ${ }^{4}$ This suggests that the disease can be controlled, and various community and population-based intervention strategies have been applied to interfere with the de-remineralization process contributing to reduce mineral loss. Methods to control caries based on the restriction of sugar consumption, use of fluoride, and placement of occlusal sealants have been implemented. The strategy based on restriction of sugar consumption aims not only to reduce the consumption, but also focuses on the use of alternative sweetening compounds that are not fermented by bacteria as well as substances with putative anti-caries activity.

Another well-established strategy for caries control involves the use of fluoride which interfere with the physicochemical process of tooth (enamel/dentine) mineral dissolution. ${ }^{7}$ The presence of fluoride in the oral cavity not only reduces demineralization but also enhances tooth re-mineralization. ${ }^{8}$ Intervention strategies typically rely on different approaches to deliver fluoride into the oral cavity, and these can be classified into different categories based on their level of action, as follows: community level (water, salt, and milk fluoridation), individual level (fluoride dentifrices and mouthrinses), and clinical interventions (gel, varnish, foam). From the public health perspective, individual actions that are not isolated but are a part of a general systematic effort aiming to produce an effect in the population are considered to be actions at the community level. These include school programs incorporating the use of fluoridated mouthwashes and supervised tooth-brushing with fluoridated toothpastes. Irrespective of the approach employed, the common goal of all of these interventions is to maintain a certain concentration of fluoride in the oral cavity so as to enhance its preventive and therapeutic effects.

When used within the framework of a community program, the placement of dental sealants to cover pits and fissures on the occlusal surfaces of teeth has also been found to be effective in controlling caries, particularly in high-risk individuals. ${ }^{9}$ The fissured occlusal surfaces of first permanent molars as well as their lower buccal and upper lingual pits are highly susceptible to caries lesions, and the use of occlusal sealants in these areas not only prevents the onset of caries lesions by interfering with bacterial adhesion and growth but also acts as a physical barrier and helps to seal dental irregularities, thus protecting the tooth surfaces from interaction with bacterial acids responsible for demineralization. There are a wide 
range of commercially available occlusal sealant materials, the most common of which are resins and glass-ionomer based cements.

Although such community interventions and strategies have been adopted for caries control, compiled data on their use in Latin American and Caribbean countries (LACC) or summarized evidence on their effectiveness are scarce. Further exploration of the extent of implementation of these measures in LACC will not only help develop a better understanding of the actual scenario in these countries, but also guide public health policies and decision-making with regard to the appropriateness of community and individual-level interventions for caries control within the context of these regions. Therefore, the aim of this report was to summarize the main scientifically documented community interventions and strategies based on restriction of sugar consumption, use of fluoride, and the use of occlusal sealants for caries control in LACC.

\section{Methodology}

\section{Search method and inclusion/exclusion criteria}

Three separate systematic searches were carried out to identify studies related to community interventions and strategies aiming to control caries in LACC by a) restricting sugar consumption, b) using fluoride, and c) placement of dental sealants. Prior to this, the researchers were calibrated by carrying out a pilot search aiming to identify studies focusing on restriction of sugar exposure and use of fluoride using the database, PubMed.

The search string used for identifying interventions restricting sugars consumption for caries control in LACC was as follows: [Sugar OR Sugars OR Dietary Sugars OR Dietary Sucrose OR High Fructose Corn Syrup OR Disaccharides OR Lactose OR Monosaccharides OR Sugar Sweetened Beverages OR Sugar-Added Beverages OR Sweetened Drinks OR Sugar-Sweetened Soft Drinks OR Sugar Sweetened Soft Drinks OR Sugar-Sweetened Sodas OR Candies OR Caramel Candy OR Sugar (MeSH terms) OR Sugar-Sweetened beverages (MeSH terms) OR Candy (MeSH terms)] AND (Dental caries) AND (strategy
OR program OR policy OR prevention OR protection OR regulation OR control OR restriction OR effective).

The search string used for identifying interventions using fluoride for caries control in LACC was as follows: [Fluoride OR Fluoridated toothpaste OR Fluoridated dentifrice OR Fluoridated varnish OR Fluoridated water OR Acidulated Fluoride Phosphate OR Topical Fluorides OR Fluoride Varnishes OR Fluoride gels OR Fluoridated gels OR Fluoride foams OR fluoridated foams OR Silver diamine fluoride OR Milk Fluoridation OR Water Fluoridation OR Fluoridation OR Salt Fluoridation OR Fluorides (MeSH terms) OR Sodium fluoride (MeSH terms) OR Acidulated Phosphate Fluoride (MeSH terms)] AND (strategy OR program OR policy OR prevention OR protection OR regulation) AND (coverage OR effective OR extent) NOT (Rats OR Mice OR "In Vitro" OR "In Situ” OR Cell OR Bovine). Additionally, LACC names were also included as a search term to increase accuracy.

These pilot searches recovered 239 studies on sugars restriction and 561 studies on fluoride use via community interventions and strategies for caries control. The Rayyan web-tool was used during the selection/exclusion process, ${ }^{10}$ and a total of 100 studies from each topic were selected to be independently evaluated by two reviewers (sugars restriction: B.A.C. and R.A.G.; fluoride use: A.P.R.F. and P.F.). The titles and abstracts were screened for eligibility, and the selection criteria were established during this stage. Studies reporting strategies based on the restriction of sugar consumption or fluoride use for caries control in at least one Latin American and Caribbean country were included, while those that were of the wrong publication type, did not address the research question, or did not have an abstract available were excluded.

Thereafter, final searches for studies on interventions restricting sugar consumption and fluoride (June 17, 2020) use were carried out on the PubMed, LILACS, and SciELO databases using the same keywords with minor modifications relevant to each database. A third systematic search to identify strategies based on the use of pit and fissure sealants for caries control (July 28, 2020) was also carried out on PubMed using the following search string: (Sealants 
OR Pit Fissure Sealants OR Dental Sealants OR Tooth Sealants OR Fissure Sealants) AND (strategy OR program OR policy OR prevention OR protection OR regulation) AND (coverage OR effective OR extent) AND (Belize OR Costa Rica OR El Salvador OR Guatemala OR Honduras OR Mexico OR Nicaragua OR Panama OR Argentina OR Bolivia OR Brazil OR Chile OR Colombia OR Ecuador OR French Guiana OR Guyana OR Paraguay OR Peru OR Suriname OR Uruguay OR Venezuela OR Cuba OR Dominican Republic OR Haiti OR Guadeloupe OR Martinique OR Puerto Rico OR Saint-Barthélemy OR Saint-Martin) NOT (Rats OR Mice OR "In Vitro" OR "In Situ" OR Cell OR Bovine). The same search strings were used on the LILACS and SciELO databases with minor relevant modifications.

The studies recovered from these searches were then uploaded in to the Rayyan web-tool and organized into the three relevant categories. Duplicated studies were identified and removed, and each topic was independently evaluated by two reviewers (sugar restriction: B.A.C. and R.A.G.; fluoride use: A.P.R.F. and P.F.; and dental sealant: A.P.R.F. and P.F.). The titles and abstracts were screened for eligibility. Studies focusing on the restriction of sugar consumption were categorized based on the intervention strategy, as follows: education, sugar replacement, and food supplementation. Studies focusing on fluoride use were categorized based on the method of delivery used, as follows: water, salt, milk, dentifrice, acidulated phosphate fluoride (APF) gel, mouth-rinse, and varnish. Lastly, studies focusing on the use of dental sealants were evaluated as a single topic without further categorization. The studies within the three topics were also organized according to LACC, and the current report is structured to provide data on at least one representative study from each LACC identified as using restriction of sugar consumption, fluoride use, or dental sealant as a strategy for caries control. The search strategy and study selection methods have been summarized in Figure.

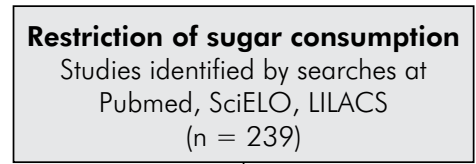

Studies after duplicate removal $(n=215)$

Studies screened by titles and abstracts $(n=17)$

Full text article assessed for eligibility $(n=13)$

\begin{tabular}{|c|} 
(n $=13)$ \\
\hline Studies were categorized based on \\
the intervention strategy: education, \\
sugar replacement, and food \\
supplementation.
\end{tabular}

A representative study for each type of intervention described by LACC was included in the report $(n=3)$

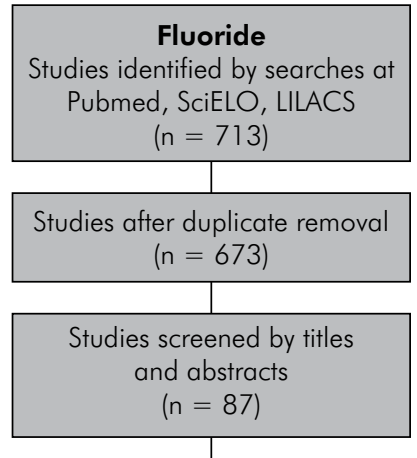

Full text article assessed for eligibility $(\mathrm{n}=87)$

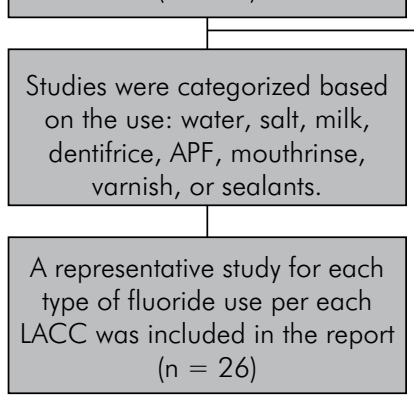

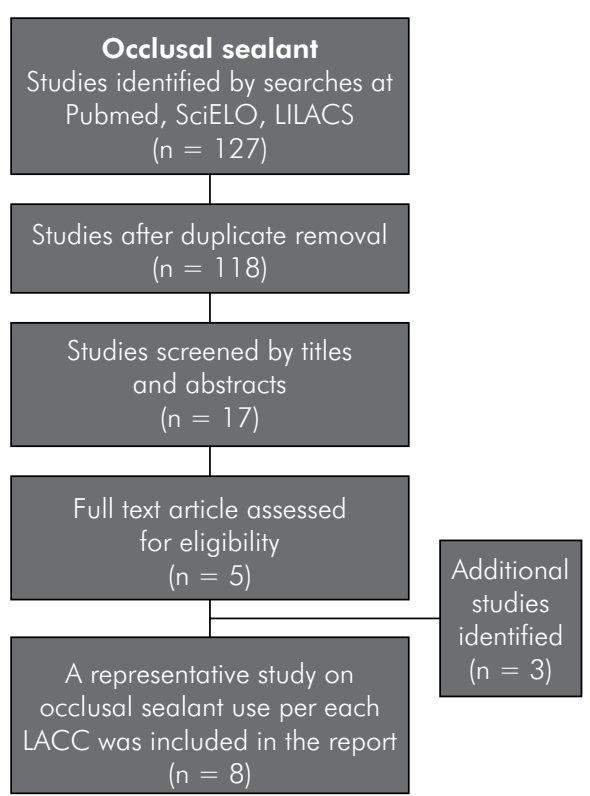

Figure. Summary of systematic search method for identification of interventions based on restriction of sugar consumption, fluoride use, and placement of occlusal sealants for caries control in Latin American and Caribbean countries (LACC). 


\section{Results}

The identified studies focusing on interventions using restriction of sugar consumption, fluoride use, or dental sealant as a strategy for caries control in LACC are shown in Tables 1, 2 and 3, respectively. The search method (Figure) yielded the highest number of studies focusing on interventions based on fluoride use (Table 2), followed by a smaller number of studies focusing on restriction of sugar consumption (Table 1) and use of occlusal sealants (Table 3) for caries control.

Several LACC such as Belize, Brazil, Chile, Colombia, Puerto Rico, and Venezuela adopted interventions based on restricted exposure to sugar via food supplementation, sugar replacement, and education. Two studies (one of which was a pilot study) reported interventions aimed at food supplementation using probiotics, while another focused on a school-based intervention ${ }^{11}$ that showed a significant reduction in caries upon administration of milk twice per day among preschool children. The most common methods of sugar replacement for caries control involved the use of chewing gums (reported by 6 out of 7 relevant studies) and sorbitol mints (reported by one study), and the majority of studies reported adopting a polyol-based approach to replacing sucrose. Four of the screened publications reported findings from a single study and its follow-up carried out in Belize, ${ }^{12}$ and their results suggested

Table 1. Interventions based on restriction of sugar consumption for dental caries control in Latin American and Caribbean countries (LACCs).

\begin{tabular}{|c|c|c|c|}
\hline LACC & Author & Intervention & Summarized findings \\
\hline \multirow{4}{*}{ Chile } & \multirow{4}{*}{$\begin{array}{l}\text { Rodríguez et al., } \\
2016^{11}\end{array}$} & \multirow{4}{*}{$\begin{array}{l}\text { Food } \\
\text { supplementation }\end{array}$} & Aim: To determine the effects of probiotic-milk supplementation on caries incidence in preschool children. \\
\hline & & & $\begin{array}{l}\text { Methodology: Triple-blinded, placebo-controlled randomized trial; } 261 \text { children aged } 2 \text { - } 3 \\
\text { years old from } 16 \text { nursery schools in Santiago, Chile were included. The nursery schools were } \\
\text { allocated into two arms, as follows: } 1) \text { Intervention arm: } 150 \mathrm{~mL} \text { of milk supplemented with } \\
\text { Lactobacillus rhamnosus } \mathrm{SP1} 1\left(10^{7} \mathrm{CFU} / \mathrm{mL} \text { ) administered on weekdays for } 10 \text { months, and 2) }\right. \\
\text { Control arm: non-supplemented cow milk administered. Follow-up lasted } 10 \text { months with a clinical } \\
\text { exam at the end. Dropout rate: } 21 \% \text {. }\end{array}$ \\
\hline & & & Outcomes: Caries increment using ICDAS. \\
\hline & & & $\begin{array}{l}\text { Results: The probiotic (intervention) group showed a lower caries prevalence }(54.4 \%) \text { compared to } \\
\text { the control group ( } 65.8 \%) \text {. Caries incidence (cavitated lesions; ICDAS } 5-6 \text { ) in the intervention group } \\
\text { was significantly lower }(9.7 \%) \text { compared to the control group }(24.3 \%) \text {, with OR=0.35 ( }<<0.05) \text {. }\end{array}$ \\
\hline \multirow{4}{*}{ Belize } & \multirow{4}{*}{$\begin{array}{l}\text { Makinen et al., } \\
1995^{12}\end{array}$} & \multirow{4}{*}{$\begin{array}{l}\text { Sugar } \\
\text { replacement }\end{array}$} & Aim: To determine the cariogenicity of sucrose-based chewing gums in children. \\
\hline & & & $\begin{array}{l}\text { Methodology: Double-blinded cohort study; } 1277 \text { children (mean age: } 10.2 \text { years) included. Nine } \\
\text { study arms: 1) Control (no gum); 2), 3), 4) and 5): Xylitol used in different amounts (range: } 4.3-9.0 \\
\text { g/day); 6) and 7): Xylitol/Sorbitol (range of polyols: } 8.0-9.7 \mathrm{~g} / \text { day); } 8 \text { ): Sorbitol (9.0 g/day); and 9) } \\
\text { Sucrose ( } 9.0 \mathrm{~g} / \text { day). Gum use was supervised and the program was implemented for } 40 \text { months. }\end{array}$ \\
\hline & & & Outcome: Modified WHO procedure for identification of non-cavitated and cavitated carious lesions. \\
\hline & & & $\begin{array}{l}\text { Results: Sucrose gums increased the caries scores (RR } 1.20 ; \mathrm{Cl} 0.96-1.49 ; \mathrm{p}=0.1128 \text { ), while } \\
\text { sorbitol gums decreased the caries scores (RR } 0.74 ; \mathrm{Cl} 0.6-0.92 ; \mathrm{p}=0.0074 \text { ). Although all four } \\
\text { variants of Xylitol gums were effective in decreasing caries rates, the most effective were those containing } \\
100 \% \text { Xylitol (RR } 0.27 ; \mathrm{Cl} 0.20-0.36 ; \mathrm{p}=0.0001 \text { ). The Xylitol/Sorbitol combination decreased caries } \\
\text { incidence compared to the control group, but was less effective than the Xylitol only group. }\end{array}$ \\
\hline \multirow{4}{*}{ Brazil } & \multirow{4}{*}{$\begin{array}{l}\text { Feldens et al, } \\
2007^{13}\end{array}$} & \multirow{4}{*}{ Education } & $\begin{array}{l}\text { Aim: To determine the effectiveness of home visits to educate mothers on the effects of breast } \\
\text { feeding and weaning on early childhood caries (ECC). }\end{array}$ \\
\hline & & & $\begin{array}{l}\text { Methodology: Randomized community trial including } 500 \text { mother-child pairs (intervention group: } \\
200 \text {, control group: } 300 \text { ). Intervention: Advice } 10 \text { days after the child's birth, repeated monthly up } \\
\text { to } 6 \text { months, and then again at } 8,10 \text {, and } 12 \text { months. }\end{array}$ \\
\hline & & & Outcomes: Early childhood caries at 12 months (decayed surfaces). \\
\hline & & & $\begin{array}{l}\text { Results: Intervention group: } 10.2 \% \text { with ECC; Control group: } 18.3 \% \text { with ECC. The intervention } \\
\text { group had } 48 \% \text { lower odds of developing caries (OR 0.52, CI } 0.27-0.97 \text { ) compared to the } \\
\text { control group. Mean DS was lower for the intervention group (0.37) than the control group (0.63). } \\
\text { The intervention group also exhibited longer duration of exclusive breast feeding, later introduction } \\
\text { of sugar to the diet, and lower probability of eating sugary foods. }\end{array}$ \\
\hline
\end{tabular}


Table 2. Fluoride use for dental caries control in Latin American and Caribbean countries (LACCs).

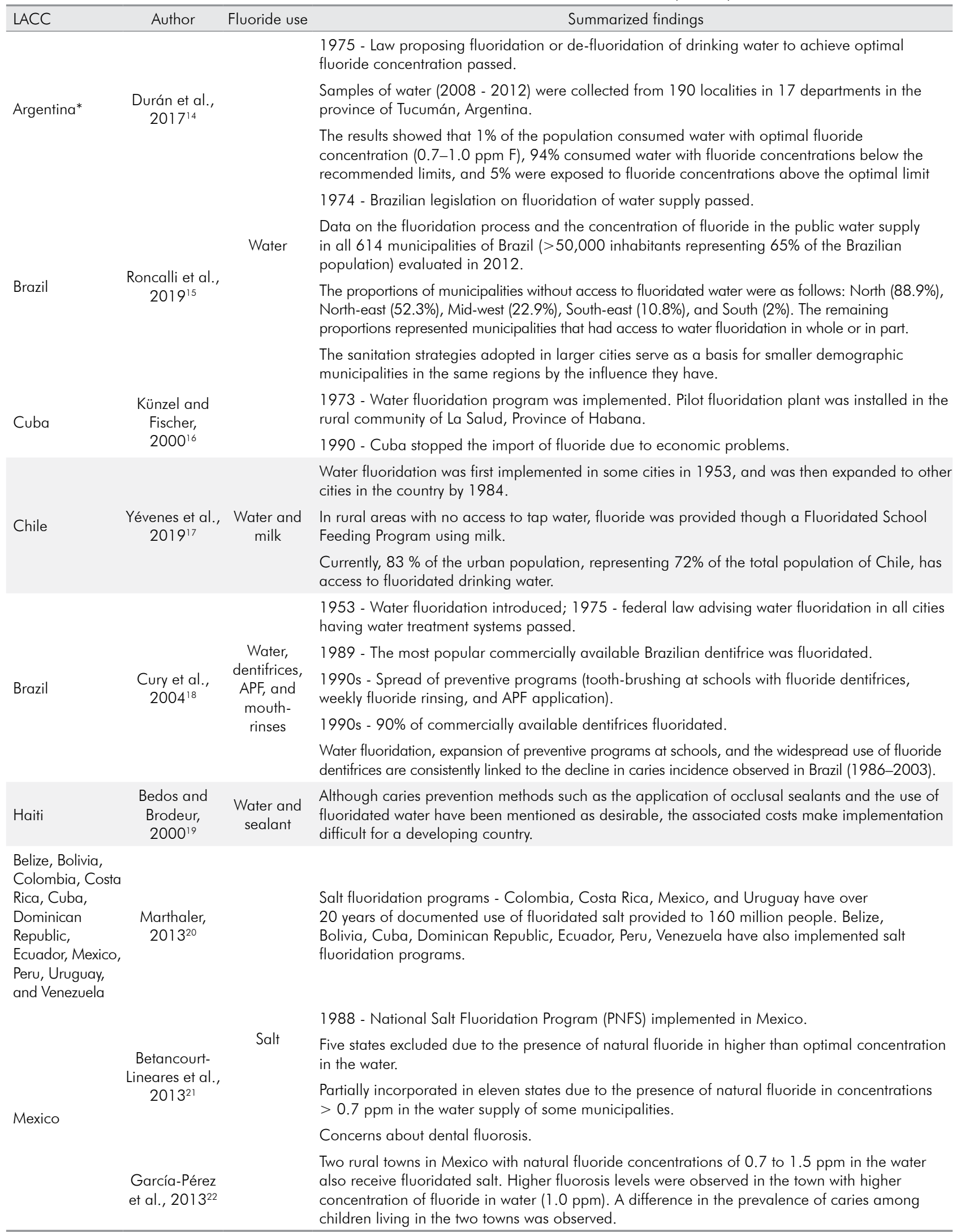




\begin{tabular}{|c|c|c|c|}
\hline LACC & Author & Fluoride use & Summarized findings \\
\hline & & & 1995 - Salt fluoridation program implemented. \\
\hline Venezuela & $\begin{array}{l}\text { Montero et al., } \\
2007^{23}\end{array}$ & & $\begin{array}{l}\text { The main sources of fluoride exposure: dentifrices ( } 1100 \mathrm{mgF} / \mathrm{L}) \text {, salt }(60-90 \mathrm{mgF} / \mathrm{L}) \text {, and } \\
\text { naturally fluoridated water with concentrations ranging from } 0.13 \text { to } 2.32 \mathrm{mgF} / \mathrm{L} \text {. Two types of } \\
\text { salts available: a) fluoridated, to be consumed in areas with concentrations of fluoride }<0.5 \\
\mathrm{mg} / \mathrm{L} \text { in drinking water, and b) non-fluoridated, to be distributed in areas with high prevalence of } \\
\text { dental fluorosis. The consumption of fluoridated salt in areas with high rates of dental fluorosis } \\
\text { only increased the risk further. }\end{array}$ \\
\hline
\end{tabular}

2007 - Law mandating fluoridation of salt (concentration range: $200-225 \mathrm{mg} / \mathrm{kg}$ ) for human consumption passed in Nicaragua.

$\begin{array}{ccc}\text { Walsh and } & \text { Salt }\end{array}$

Peru Cury et al., $2018^{25}$

\begin{tabular}{|c|c|}
\hline $\begin{array}{l}\text { Argentina, } \\
\text { Bolivia, } \\
\text { Brazil, Chile, } \\
\text { Colombia, Costa } \\
\text { Rica, Cuba, } \\
\text { Dominican } \\
\text { Republic, } \\
\text { Ecuador, El } \\
\text { Salvador, } \\
\text { Guatemala, } \\
\text { Honduras, } \\
\text { Mexico, } \\
\text { Nicaragua, } \\
\text { Panama, } \\
\text { Paraguay, Peru, } \\
\text { Uruguay, and } \\
\text { Venezuela }\end{array}$ & $\begin{array}{l}\text { Gillespie and } \\
\text { Baez, } 2005^{26}\end{array}$ \\
\hline $\begin{array}{l}\text { Brazil, and } \\
\text { Uruguay }\end{array}$ & $\begin{array}{c}\text { Fabruccin } \\
\text { et al., } 2016^{27}\end{array}$ \\
\hline Cuba & $\begin{array}{l}\text { García Melián } \\
\text { et al., } 2002^{28}\end{array}$ \\
\hline
\end{tabular}

Colombia

Agudelo-

Suárez et al., Salt, water, $2013^{29}$ water
Fluoride concentration in 11 brands of salt sold in Managua, Nicaragua evaluated.

Of these, only two brands presented optimal fluoride concentration, as required by the legislation. Among the other brands, 2 were not fluoridated and five had fluoride concentrations below the mandated range.

Surveillance systems for the salt fluoridation program should be improved.

Peruvian legislation states that salt for human consumption should be fluoridated (concentration range: $200-250 \mathrm{mg} \mathrm{F} / \mathrm{kg}$ ).

Fluoride concentration in four brands of salt commercially available in Lima, Peru were evaluated.

The fluoride concentrations were not homogeneous in any of the salt samples (ranging from 72.0 to $1449.7 \mathrm{mg} \mathrm{F} / \mathrm{kg}$ ).

The manufacturing and sanitary surveillance of fluoride salt in Peru should be improved.

1964 - 1972 - Colombia Trial for use of fluoridated salt - The clinical results showed changes in dental caries prevalence, and the efficacy of fluoridated salt was comparable to that of water fluoridation.

1972 - 1986 - Discussion to implement salt fluoridation in Latin American and Caribbean countries. Colombia was committed to fluoridated salt. Brazil, Chile, and Argentina were interested in expanding water fluoridation.

1986 - 1992 - Costa Rica, Uruguay, Peru, and Mexico (areas with low fluoride) implemented fluoridated salt programs. Since Nicaragua and El Salvador already had natural fluoride in their water supply, the need for additional fluoride sources had to be evaluated.

1992 - 2004 - Honduras, Guatemala, Paraguay, and Nicaragua implemented fluoridated salt programs. Argentina commenced production of fluoridated salt. Venezuela, Bolivia, Cuba, Dominican Republic, and Ecuador began initiating programs. Most countries in Latin America, Salt and with the exceptions of Brazil, Chile, and Panama, had implemented use of fluoridated salt.

Two population-based oral health surveys of 12-year-old school children exposed to a) artificially fluoridated water in Porto Alegre, South Brazil, and b) artificially fluoridated salt in Montevideo, Uruguay.

"Salt fluoridation is recommended by the WHO as an alternative method when water fluoridation might be unavailable for technical, financial, or sociocultural reasons."

Furthermore, the salt fluoridation program in Uruguay is limited to salt for domestic use only, with no coverage of public and private canteens, restaurants, and bakeries as recommended by the WHO. In Porto Alegre, most of the water for human consumption, available through the public water supply system or as commercially available bottles, is fluoridated.

2001 - Cuba implemented a salt fluoridation program. However, areas with natural fluoride present in the water supply do not receive fluoridated salt and are also monitored to ensure optimal levels of fluoride concentration for caries control.

The use of fluoride as a public health strategy may be hindered by the prevalence and severity of dental fluorosis. This is further complicated by a general lack of knowledge regarding dental fluorosis (even by health professionals) and the absence of monitoring to ensure appropriate fluoride use.

This is a common concern in most Latin American countries with salt and water fluoridation programs; however, the occurrence of high concentrations of fluoride in the water in some regions may result in dental fluorosis, as seen in some parts of Mexico.

From a public health perspective, policies and strategies should attempt to eliminate or reduce simultaneous sources of systemic fluoridation (water, salt, or other supplements). 


\begin{tabular}{|c|c|c|c|}
\hline LACC & Author & Fluoride use & Summarized findings \\
\hline \multirow{6}{*}{ Peru } & \multirow{6}{*}{$\begin{array}{l}\text { Vallejos- } \\
\text { Ragas and } \\
\text { Tineo-Tueros, } \\
2015^{30}\end{array}$} & \multirow{6}{*}{$\begin{array}{l}\text { Salt, } \\
\text { mouth-rinse, } \\
\text { APF, } \\
\text { milk, and } \\
\text { dentifrices }\end{array}$} & $\begin{array}{l}1964 \text { - } 2 \% \text { sodium fluoride solution applied on the tooth surfaces. Four applications at different } \\
\text { time points in the child's life }(3,7,10 \text {, and } 13 \text {-years-old). }\end{array}$ \\
\hline & & & 1984 - Salt fluoridation program implemented. \\
\hline & & & 1985 to 2008 - 0.2\% sodium fluoride mouth-rinse administered to children in public schools. \\
\hline & & & $\begin{array}{l}1995 \text { to } 2000-1.23 \% \text { acidulated phosphate fluoride (APF) gels used to complement the } \\
\text { mouth-rinse program. }\end{array}$ \\
\hline & & & 1999 - 2004 - Milk fluoridation program \\
\hline & & & 2001 - Regulations regarding the addition of fluoride to dentifrices and mouth-rinses published. \\
\hline \multirow{4}{*}{ Brazil } & \multirow{4}{*}{$\begin{array}{l}\text { Conde et al., } \\
2003^{31}\end{array}$} & \multirow{15}{*}{ Dentifrice } & Five dentifrices most commonly used in Brazil were evaluated (1000 to 1500 ppm F). \\
\hline & & & All of the dentifrices were manufactured in Brazil. \\
\hline & & & MFP was present in $100 \%$ of the samples analyzed. \\
\hline & & & $\begin{array}{l}\text { All dentifrices contained a total soluble fluoride (TSF) concentration greater than } 1000 \mathrm{ppm} F \text { to } \\
\text { provide an anti-caries effect. }\end{array}$ \\
\hline \multirow{5}{*}{ Chile } & \multirow{4}{*}{$\begin{array}{l}\text { Fernández } \\
\text { et al., } 2017^{32}\end{array}$} & & Thirty dentifrices commercially available in the three main chain drugstores in Chile were evaluated. \\
\hline & & & $\begin{array}{l}\text { Eighteen dentifrices targeting the general public ( } 1100 \text { to } 1450 \text { ppm F) contained } 78 \% \text { NaF, } \\
17 \% \text { MFP, and } 5 \% \text { NaF/MFP. }\end{array}$ \\
\hline & & & Twelve dentifrices targeting children (422 to 1100 ppm F) contained 58\% NaF and 42\% MFP. \\
\hline & & & $\begin{array}{l}\text { Among dentifrices targeting children, only } 25 \% \text { contained }>1000 \mathrm{ppm} \mathrm{F} \text {. A total of } 42 \% \\
\text { of dentifrices had low fluoride concentrations ( } 422 \text { to } 475 \mathrm{ppm} \mathrm{F} \text { ) with } \mathrm{MFP} \text { and } \mathrm{CaCO}_{3} \text { as } \\
\text { abrasives, thus lowering the TSF further. }\end{array}$ \\
\hline & \multirow{6}{*}{$\begin{array}{l}\text { Chavez et al., } \\
2019^{33}\end{array}$} & & Two dentifrices contained $\mathrm{NaF}$ with $\mathrm{CaCO}_{3}$ as abrasive (incompatible, decrease soluble fluoride). \\
\hline \multirow{5}{*}{ Peru } & & & $\begin{array}{l}\text { Twenty-three dentifrices, of which four did not have fluoride and } 19 \text { had fluoride in } \\
\text { concentrations ranging from } 452 \text { to } 1450 \text { ppm F, targeting children were evaluated (Lima, Peru). }\end{array}$ \\
\hline & & & All of the dentifrices were manufactured in Ecuador, Peru, USA, China, Mexico, Brazil, and Spain. \\
\hline & & & NaF was present in $70 \%$ of the samples analyzed and MFP was present in $30 \%$. \\
\hline & & & $\begin{array}{l}\text { Most dentifrices exhibited total fluoride (TF) concentration equal to that mentioned on the label. However, } \\
\text { one dentifrice exhibited a concentration of } 515.1 \mathrm{ppm} \mathrm{F} \text {, despite advertising } 1450 \mathrm{ppm} \text { on the packaging. }\end{array}$ \\
\hline & & & $\begin{array}{l}\text { The majority of children's dentifrices were fluoridated, although only } 53 \% \text { contained a TSF } \\
\text { concentration greater than } 1000 \mathrm{ppm} \mathrm{F} \text { (necessary for anti-caries effect). }\end{array}$ \\
\hline Uruguay & $\begin{array}{l}\text { Loureiro } \\
\text { et al., } 2017^{34}\end{array}$ & & $\begin{array}{l}\text { Six commercial brands of children's dentifrices available in Uruguay were tested (500 to } 1100 \mathrm{ppm} \\
\text { F). The dentifrices were manufactured in Uruguay, Mexico, and Brazil. NaF was present in } 83 \% \text { of the } \\
\text { samples analyzed and MFP was present in } 17 \% \text {. Two dentifrices contained } \mathrm{NaF}_{\text {with }} \mathrm{CaCO}_{3} \text { as abrasive } \\
\text { (incompatible, }>50 \% \text { fluoride insoluble). One dentifrice was formulated with MFP and } \mathrm{CaCO}_{\text {a }} \text { as } \\
\text { abrasive (compatible). Three dentifrices contained NaF and Silica, resulting in TSF concentration similar to } \\
\text { TF. Only 33\% contained a TSF concentration greater than } 1000 \text { ppm F (necessary for anti-caries effect). }\end{array}$ \\
\hline \multirow{4}{*}{ Brazil } & \multirow{4}{*}{$\begin{array}{l}\text { Iwakura } \\
\text { and Morita, } \\
2004^{35}\end{array}$} & \multirow{4}{*}{ Mouth-rinse } & 1970s - The role of fluoride mouth-rinse programs in caries control strategies was re-evaluated. \\
\hline & & & $\begin{array}{l}\text { In Brazil, the application of } 0.2 \% \text { sodium fluoride mouth-rinse has been one of the most } \\
\text { commonly used methods of preventing caries after the fluoridation of public water supply. }\end{array}$ \\
\hline & & & $\begin{array}{l}\text { In Londrina (water fluoridation started in 1972), Paraná State, the weekly fluoride mouth-rinse } \\
\text { program (which completed } 20 \text { years in 2001) targeted } 248,872 \text { school children aged } 6 \text { to } 12 \text { years. }\end{array}$ \\
\hline & & & $\begin{array}{l}2001 \text { - The results showed that the fluoride mouth-rinse program (twice/week using } 0.2 \% \text { sodium fluoride } \\
\text { mouth-rinse) was not associated with a lower prevalence of caries, both in public and private schools. }\end{array}$ \\
\hline Brazil & $\begin{array}{l}\text { Arruda et al., } \\
2012^{36}\end{array}$ & & $\begin{array}{l}\text { A great heterogeneity in the distribution of dental caries was observed, further complicated by } \\
\text { inequalities in access to fluoride, particularly in rural communities. Fluoride varnish ( } 5 \% \mathrm{NaF}) \\
\text { application was evaluated. }\end{array}$ \\
\hline Chile & $\begin{array}{l}\text { Palacio et al., } \\
2019^{37}\end{array}$ & & $\begin{array}{l}\text { A decision analytic model (DAM)-based cost-effectiveness analysis aimed to evaluate the costs and effects } \\
\text { (in terms of caries prevalence) of a Chilean fluoride varnish program. Cost was found to be a limitation. }\end{array}$ \\
\hline \multirow[t]{2}{*}{$\begin{array}{l}\text { Dominican } \\
\text { Republic }\end{array}$} & \multirow[t]{2}{*}{$\begin{array}{l}\text { Abreu- } \\
\text { Placeres } \\
\text { et al., } 2019^{38}\end{array}$} & Varnish & $\begin{array}{l}\text { A randomized clinical trial (including } 180 \text { children aged } 6 \text { to } 7 \text { years and considered to be at } \\
\text { high risk of developing caries) evaluated the effectiveness of fluoride varnish (FV) application } \\
\text { in the prevention of carious lesions on erupting first permanent molars. Groups evaluated: (i) } \\
\text { control, (ii) FV applied every } 3 \text { months, and (iii) FV applied every } 6 \text { months. }\end{array}$ \\
\hline & & & $\begin{array}{l}\text { FV application every } 3 \text { months reduced the risk of developing caries lesions to a greater extent } \\
\text { than FV application every } 6 \text { months and the control group. }\end{array}$ \\
\hline El Salvador & $\begin{array}{l}\text { Dabiri et al., } \\
2016^{39}\end{array}$ & & $\begin{array}{l}\text { A rural community-based program (Asociación Salvadoreñna Pro-Salud Rural - ASAPROSAR) } \\
\text { evaluated the use of fluoride varnish application as a preventive measure for dental caries. }\end{array}$ \\
\hline
\end{tabular}

*Although the key focus of the publication is exposure to fluoride, we carried out a critical review of strategies for the use of fluoride in LACCs. 
Table 3. The use of occlusal sealants for dental caries control in Latin American and Caribbean countries (LACCs).

\begin{tabular}{|c|c|c|}
\hline LACC & Authors & Summarized findings \\
\hline \multirow{3}{*}{ Brazil } & \multirow{3}{*}{$\begin{array}{l}\text { Goldman } \\
\text { et al., } 2017^{40}\end{array}$} & $\begin{array}{l}\text { Children (aged 6-7 years) from public primary schools in a low socioeconomic area of Paranoá city, Brasilia, } \\
\text { Brazil, participated in this study. }\end{array}$ \\
\hline & & $\begin{array}{l}\text { A 3-year cost-effectiveness analysis was carried out to compare the ability of composite resins, atraumatic } \\
\text { restorative treatment (ART) using high-viscosity glass-ionomer cement sealants, and supervised tooth-brushing to } \\
\text { prevent cavitated dentine carious lesions in high risk first permanent molars. }\end{array}$ \\
\hline & & $\begin{array}{l}\text { The results showed that supervised tooth-brushing had lower costs and higher savings per cavitated dentine } \\
\text { carious lesion prevented compared to composite resin and ART sealants. }\end{array}$ \\
\hline \multirow[t]{2}{*}{ Chile } & \multirow{2}{*}{$\begin{array}{l}\text { Espinoza- } \\
\text { Espinoza } \\
\text { et al., } 2019^{41}\end{array}$} & $\begin{array}{l}\text { The analysis model showed that the universal application of resin sealants as part of school-based sealant } \\
\text { programs in Chile would be a cost-effective measure in populations where the prevalence of caries in first } \\
\text { permanent molars was high. }\end{array}$ \\
\hline & & Public policies should include the application of sealants in children from low-income families where caries risk is high. \\
\hline \multirow[t]{2}{*}{ Colombia } & \multirow{2}{*}{$\begin{array}{l}\text { McCune et al., } \\
1979^{42}\end{array}$} & $\begin{array}{l}\text { Children (aged 6-8 years) from public schools in Medellin, Colombia, participated in this study. The half-mouth } \\
\text { technique was used to place occlusal sealant, with the contra-lateral tooth serving as a control. Evaluations } \\
\text { were conducted } 24 \text { and } 36 \text { months after sealant placement. }\end{array}$ \\
\hline & & $\begin{array}{l}\text { The incidence of caries in all sealant-treated teeth at } 36 \text { months was } 8 \% \text { compared to } 53 \% \text { in the untreated } \\
\text { control teeth, suggesting that sealants were effective in protecting the occlusal surfaces of teeth against caries. }\end{array}$ \\
\hline \multirow{2}{*}{ Costa Rica } & \multirow{2}{*}{$\begin{array}{l}\text { Ulate Jiménez } \\
\text { and Montero } \\
\text { Salazar, } \\
2007^{43}\end{array}$} & $\begin{array}{l}\text { Costa Rican children aged } 12 \text { years and going to public or private schools were examined for the presence of } \\
\text { at least one sealant on one of their permanent teeth. }\end{array}$ \\
\hline & & $\begin{array}{l}\text { The prevalence of pit and fissure sealants was } 60 \% \text { in the central region of the country, and less than } 30 \% \text { in } \\
\text { other areas of the country. }\end{array}$ \\
\hline \multirow{6}{*}{ Mexico } & \multirow{3}{*}{$\begin{array}{l}\text { Luengas- } \\
\text { Quintero } \\
\text { et al., } 2013^{44}\end{array}$} & $\begin{array}{l}2001 \text { - } 2006 \text { - The National Oral Health Program of Mexico included the use of ART sealants (high-viscosity } \\
\text { glass-ionomer cements) for caries-prone pits and fissures. }\end{array}$ \\
\hline & & $\begin{array}{l}2008 \text { - } 2012 \text { - The National Development Plan and the National Plan for Health reinforced the use of ART } \\
\text { sealants as a caries control approach. }\end{array}$ \\
\hline & & $\begin{array}{l}\text { The dentine carious lesion failure rates for the use of ART sealants in primary and permanent teeth over the } \\
2 \text {-year period were } 0 \% \text { and } 2.5 \% \text {, respectively. }\end{array}$ \\
\hline & \multirow{3}{*}{$\begin{array}{l}\text { Soto-Rojas } \\
\text { et al., } 2012^{45}\end{array}$} & $\begin{array}{l}\text { Study developed as an international service-learning program targeting small rural communities in Calnali, } \\
\text { Hidalgo, Mexico. }\end{array}$ \\
\hline & & Resin-based sealants placed in children (aged 6-15 years) living in a rural setting. \\
\hline & & $\begin{array}{l}\text { The high prevalence of caries in this rural population suggests that there is still a great need for comprehensive } \\
\text { dental public health programs. }\end{array}$ \\
\hline \multirow{2}{*}{ Peru } & \multirow{2}{*}{$\begin{array}{l}\text { Pachas } \\
\text { Barrionuevo } \\
\text { et al., } 2009^{46}\end{array}$} & $\begin{array}{l}\text { The study assessed the survival rates of ART sealants applied on the occlusal surfaces of permanent molars and } \\
\text { premolars in schoolchildren (aged 8-13 years) from a public school in Lima after a } 2 \text { year intervention follow-up. }\end{array}$ \\
\hline & & $\begin{array}{l}\text { The use of the ART technique has shown encouraging results for the prevention of dental caries. It can be } \\
\text { implemented in populations living in rural and marginal urban areas. }\end{array}$ \\
\hline Venezuela & $\begin{array}{l}\text { Fox et al., } \\
2012^{47}\end{array}$ & $\begin{array}{l}\text { Action research was applied as a strategy for caries control during the development of the Oral Epidemiological } \\
\text { Profile study. This included Atraumatic Restorative Treatment (ART), considered to be an effective and } \\
\text { economically feasible technique for vulnerable communities. }\end{array}$ \\
\hline
\end{tabular}

that replacement of sucrose in chewing gums with Xylitol was the most effective method of reducing caries in school children, followed by sorbitol or a combination of both. Importantly, favorable outcomes were seen to be more pronounced when the comparator group was "no gum control." These studies were mostly conducted by researchers based in the United States and Finland. All five studies that reported adopting educational strategies were carried out in Brazil, with 3 of them reporting on the same intervention. The educational approaches mostly involved parental counseling on feeding practices during early childhood through community interventions, ${ }^{13}$ and the majority reported significant reduction in caries rates. Some of the studies focusing on interventions restricting sugar exposure did not measure caries outcomes and used proxy variables instead. Moreover, none of the studies investigated the effects of these interventions in adults or older adult populations in the region.

Interventions based on fluoride use for caries control were mainly adopted in the following LACC: Argentina, Belize, Bolivia, Brazil, Chile, Colombia, Costa Rica, Cuba, Dominican Republic, Ecuador, 
El Salvador, Guatemala, Haiti, Honduras, Mexico, Nicaragua, Panama, Paraguay, Peru, Uruguay, and Venezuela (Table 2). Of these, the majority of the publications reported on fluoride use in Brazil (7 studies) and Chile (4 studies), while the remaining countries all had at least one study reporting fluoride-based interventions.

The main fluoride-based strategies used drinking water, refined domestic salt, cow milk, and toothpastes, while community-based interventions utilizing mouth-rinses, gels, and varnishes were documented to a lesser extent (Table 2). Although our searches identified many publications examining soluble fluoride content in commercial dentifrices used by the population, this review only included the four studies that were carried out in LACC (Brazil, Chile, Peru, and Uruguay). The remaining relevant studies included in this report focused on the use of fluoride varnishes in Brazil ${ }^{36}$ Chile,${ }^{37}$ Dominican Republic, ${ }^{38}$ and El Salvador, ${ }^{39}$ and on the use of a combination of fluoride mouth-rinses and APF gels in Brazil ${ }^{18,35}$ and Peru ${ }^{30}$. Some publications were more comprehensive and documented several strategies for fluoride use within the same country, such as in Chile, ${ }^{17}$ Cuba, ${ }^{16}$ Brazil ${ }_{1}^{18}$ Colombia,${ }^{29}$ Haiti $^{19}$ and Peru, ${ }^{30}$ or reported one or more strategies adopted in several LACC..$^{20,26,27}$ The remaining studies reported one specific strategy adopted in a single Latin American and Caribbean country.

Interventions based on the use of occlusal sealants for caries control (Table 3) were adopted in Costa Rica $^{43}$ and Mexico. ${ }^{44,45}$ The remaining studies mainly evaluated the use of occlusal sealants in local settings, focusing mainly on children at high risk of developing caries and belonging to lower socioeconomic strata or rural areas of Brazil ${ }^{40}$ Chile ${ }^{41}$ Colombia ${ }^{42} \mathrm{Peru}^{46}$ and Venezuela. ${ }^{47}$

\section{Discussion}

This report summarized the main scientifically documented community interventions and strategies based on restricted exposure to sugars, use of fluoride, and use of occlusal sealants for caries control in Latin American and Caribbean countries (LACC). The majority of the evidence focused on strategies based on fluoride use, and the results of this review are important in the context of the changes in our understanding of dental caries and possible ways to control it, defining new perspectives to control the disease in LACC. ${ }^{48}$ Dental caries, previously considered to be a transmittable infectious disease, has now been clearly understood as a non-communicable disease that can be controlled. ${ }^{1}$ This paradigm shift is also reflected in the strategies employed by LACC to control the disease.

Although fluoride has been considered as an effective agent for the control of dental caries since the 1930s, the role of exposure to sugars in caries development was only re-emphasized recently. While biofilms are ubiquitous on teeth and are constantly forming, bacteria can only produce acids that are responsible for tooth demineralization and formation of caries upon frequent exposure to sugars. ${ }^{49}$ Therefore, effective caries control strategies must include components targeting sugar consumption. It is also essential to differentiate lesion management from disease control, as limiting lesion progression through a restorative approach will only act at the tooth level. Disease control measures, however, must target behavioral, dietary, and hygiene factors for a more holistic approach. Among the dietary carbohydrates, sucrose favors the faster growth of biofilms and changes in their matrix that contribute to higher acidogenicity which, in turn, leads to increased tooth demineralization. ${ }^{4}$ However, intervention strategies based on the restriction of sugar exposure are still scarce in LACC (Table 1), and the three main approaches adopted so far are education, sugar replacement, and food supplementation. In 2015, WHO released a guideline with recommendations on the intake of free sugar to reduce the risk of non-communicable diseases such as obesity, diabetes, and dental caries in adults and children. ${ }^{50}$ Products containing high concentrations of sugar and poor nutritional content usually tend to be cheaper and are, therefore, more frequently consumed by the population, particularly low-income families. However, the limited number of studies reporting interventions based on restricting sugar exposure in LACC has made it difficult to understand the impact of these interventions in these countries, taking into consideration contextual factors. 
Further research in the field of educational programs intended to reduce the burden of untreated caries as well as studies examining the impact of these interventions in older populations are necessary.

Even though food supplementation with probiotics or putative anti-caries nutrients ${ }^{51}$ appears to be an attractive approach for caries control, there is limited evidence on their efficacy. Taking into consideration the difficulty of effectively controlling sugar intake in the Latin American and Caribbean region, reducing cariogenicity within a cariogenic background while taking sociocultural factors into consideration may represent an opportunity for caries control. Sugar replacement using alternatives such as chewing gums containing Xylitol appear to have more grounds for appropriate caries control, at least in children. ${ }^{12}$ The majority of studies exploring this were conducted several years ago in Belize by the same group of researchers who reported long-lasting effects of administration of polyol gums five times per day for more than 3 years. However, a recent systematic review conducted by Riley et al..$^{52}$ reported insufficient evidence on the effectiveness of xylitol-containing products in controlling caries, based on the low to very low-quality of evidence available on it.

Finally, education seems to be the most rational approach to controlling caries. Most programs reported in LACC have achieved caries reduction in young children through the provision of home or school-based education. ${ }^{13}$ Additionally, educating parents on correct feeding practices from early life also proved to be advantageous as it prevented the onset of diseases and ensured healthy behavioral and dietary practices that would likely persist throughout the life course. Some of the interventions reported also included provision of oral hygiene education, including reinforcement of tooth-brushing habits to mechanically remove the biofilm present on teeth. Although tooth-brushing alone without the use of fluoride dentifrices have limited effect on caries control,,$^{53}$ daily disruption of the biofilm was seen as a desirable practice.

Although interventions at the individual level by dental professionals are important for maintenance of good oral health, restriction of exposure to sugar requires intercession at the public policy level and there have been some recent developments in this area in LACC. For example, policies proposing food labeling were recently approved in Chile, México and Ecuador, and initial assessment of their effects suggest positive outcomes. ${ }^{54}$ Chile first implemented a food labeling program, wherein high-sugar foods (as well as saturated fats, calories, and salt) were labeled with a black stop sign,, 5 and it has since been reported that the purchase of such products decreased by $23.7 \%$. This was significantly higher than the effects of a sugar tax, a measure adopted in various countries around the world as well as in the LACC region (including Chile and Mexico). The findings of this review highlight the importance of incorporating measures restricting sugar exposure in every caries preventive program and also reinforce the need for further research in this area. As individualistic, clinical, and educational preventive approaches fail to tackle the underlying cause of disease, researchers have postulated that priority should be given to investment in upstream, coherent, and integrated population-wide policies such as taxes on sugary drinks and stronger regulation of advertising and promotion of sugary foods and drinks targeting children. ${ }^{56}$

Of the various fluoride delivery strategies available, the use of fluoridated water or salt were found to be the most popular options in LACC as both approaches allowed intervention at a wider community level. Several countries such as Argentina, Brazil, Colombia, Cuba, Ecuador, Jamaica, Panama, Peru, and Chile authorized fluoridation programs and began implementation in water treatment plants of certain cities; however, of these, only Brazil and Chile managed to achieve extensive coverage (Table 2). This was mainly because many countries chose to adopt salt fluoridation programs instead, based on PAHO's Regional Oral Health Plan, ${ }^{57}$ although the extent of coverage has not been documented. Moreover, some studies have shown that salt samples did not meet the required specifications s $^{24,25,29}$ and were also sold in areas with drinking water already containing optimal natural levels of fluoride for caries prevention, ${ }^{21}$ leading to increased incidence of dental fluorosis. ${ }^{23}$ A greater understanding of the natural occurrence of fluoride in water and the difficulties associated with limiting the commercialization of fluoride salt in these areas 
led to concerns regarding increased risk of dental fluorosis and the emergence of timely surveillance systems in many countries. ${ }^{14,22,29,30}$ Preventing multiple sources of fluoridation can only be achieved through policy decisions that approve regulatory mechanisms maintained by governmental institutions. Dental fluorosis is a late marker of excessive fluoride exposure, making implementation of surveillance systems focusing on the intake and quality of drinking water and other sources of fluoride necessary. Such systems must take advantage of the information and communication technologies available in order to expand their use at various levels of society. In this context, it is possible that the adoption of digital health technologies can play an important role in achieving some of the Sustainable Development Goals, ${ }^{15}$ one of which aims to achieve universal and equitable access to safe drinking water for all by 2030 .

The concentration of fluoride in water represents a basic parameter for the assessment of its quality and safety as sub-optimal levels may increase the risk of dental caries while above-optimal levels may lead to dental fluorosis. ${ }^{58}$ Although some LACC have clear policies on the use of fluoride, there are still many that do not, suggesting the need for prioritization of investigations into the natural occurrence of fluoride in water and the development of measures necessary to achieve levels optimal for caries prevention. ${ }^{9}$ Where this is not possible, population-wide strategies such as fluoridated salt or milk should be considered as the possibility of two or more simultaneous sources of fluoride intake can then be eliminated or reduced..$^{29}$

Water and salt fluoridation programs have contributed significantly to the decline in dental caries observed in LACC. However, for several reasons beyond the scope of this article, these strategies are often not homogeneously implemented in all regions of the countries and, therefore, sometimes do not reach the populations most vulnerable to the development of caries. Greater professional advocacy and involvement of other sectors representative of the populations are necessary in order to drive governmental actions necessary for the expansion of these programs where appropriate and re-assessment of public policies where they have been implemented already. Remote and rural areas are seldom favored by these programs, and urgent development and implementation of customized interventions are necessary. The use of fluoridated milk as a community level intervention has been reported in some rural areas of Chile. ${ }^{17}$ However, targeting culturally appropriate, economically sustainable caries control interventions to rural populations and native ethnic groups such as indigenous people ( $>45$ million and over 800 ethnic groups), quilombolas (African-origin), and riverside Amazonian people remains a crucial challenge.

Fluoride dentifrices are another globally popular strategy for caries control ${ }^{59}$ as they represent the most rational individual level approach that promotes biofilm removal during tooth-brushing while simultaneously delivering fluoride into the oral cavity. The mechanical removal of dental biofilm by daily tooth-brushing not only controls the development of dental caries but also helps in the prevention of periodontal diseases. A single episode of manual tooth-brushing may reduce dental biofilm up to $42 \% .{ }^{60}$ It is also noteworthy that complete removal of the biofilm is challenging, especially in areas of the mouth that are difficult to access while brushing and, therefore, are more susceptible to disease. Therefore, daily release of fluoride into the oral cavity via dentifrice formulations represents a necessary strategy for caries control and should be encouraged regardless of the presence of water or salt fluoridation programs. Moreover, additives have been incorporated into fluoride toothpastes in an attempt to improve its anticaries effect. These substances include arginine, baking soda, calcium glycerophosphate, CPP-ACP, CPP-ACPF, and sodium hexametaphosphate. Promising findings have been reported for some of them. Hence, there is good reason to believe that new technologies should be investigated further as they have the potential to complement and enhance the effects of fluoride and reach the status of effective innovations in caries prevention.

A common characteristic of most commercially available dentifrices in LACC is the use of calcium carbonate $\left(\mathrm{CaCO}_{3}\right)$ as abrasive (Table 2). This is mainly because it is cheaper than silica and is, therefore, more widely used, particularly in low-income families , being an affordable toothpaste formulation. ${ }^{61}$ However, $\mathrm{CaCO}_{3}$ abrasive is only compatible with monofluorlophosphate (MFP) as chemically soluble fluoride tend to remain 
stable in its presence. The ion fluoride present in sodium fluoride $(\mathrm{NaF})$, stannous fluoride $\left(\mathrm{SnF}_{2}\right)$, or amine fluoride $(\mathrm{AmF})$ react with the calcium present in $\mathrm{CaCO}_{3}$ abrasive, dramatically, decreasing the soluble fluoride concentration and resultant anti-caries effect. Despite this interaction is a well-known fact, $\mathrm{NaF}$ was detected in several $\mathrm{CaCO}_{3}$-based dentifrice formulations sold in Chile ${ }^{32}$ and Uruguay, ${ }^{34}$ raising questions regarding the amount of soluble fluoride present in the formulations. In addition to an increase in the amount of non-fluoridated dentifrices available in the market, there are also a wide range of formulations with low concentrations of fluoride which certainly affect their potential to control caries. Consequently, proper legislations ${ }^{62}$ that regulate the amount of soluble fluoride present in dentifrices targeting adults as well as children so as to achieve optimal levels for caries control are necessary in LACC. Evidence shows that use of dentifrices containing at least $1000 \mathrm{ppm}$ of fluoride twice per day is highly effective in caries prevention, ${ }^{63,64,65}$ emphasizing a need to encourage their use in the population.

Other less frequently reported approaches of fluoride delivery in LACC include mouth-rinses, APF gels, and varnishes. Fluoride mouth-rinses have been adopted as an individual level, school-based intervention in Brazil ${ }^{18,35}$ and Peru, ${ }^{30}$ although it is likely that they were also implemented in other LACC. The preventive effect of mouth-rinses has been reviewed as other fluoride sources (e.g., water, salt, toothpaste) may be present, contributing to caries control.$^{65} \mathrm{APF}$ gels and fluoride varnishes represent a professional approach to fluoride delivery, and studies reporting their use in LACC did so in the context of specific populations only and not in a clinical environment. School-based programs incorporating APF gel application as a complementary approach for mouth-rinses have been reported in Brazil ${ }^{18}$ and Peru, ${ }^{30}$ while the use of fluoride varnishes as a desirable preventive public health measure targeting high-caries-risk populations living in remote and rural areas without access to fluoridated salt or water have been reported in Brazil,${ }^{36}$ Chile, ${ }^{37}$ and El Salvador. ${ }^{39}$ Although fluoride varnishes may represent a feasible public health program for this specific population, the associated costs make them a less-suitable approach in comparison to the alternatives.
Occlusal sealants have also been used as a strategy for caries control in several LACC (Table 3) such as Costa Rica ${ }^{43}$ and Mexico ${ }^{44}$, being also used in the management of caries lesions. ${ }^{66}$ One study from Costa Rica evaluated 12-year-old students across the country and found widespread use of occlusal sealants. ${ }^{43}$ The National Oral Health Program developed in Mexico in the early 2000s also included occlusal sealants as a strategy for caries control and mainly targeted rural communities. ${ }^{45}$ Occlusal sealants have been proposed as a feasible strategy for children at high risk of caries and living in remote and rural areas without access to fluoridated salt or water. The most commonly used sealant materials were found to be either resins or high-viscosity glass-ionomer cements, the latter being the preferred option in LACC areas with limited access to a proper clinical environment as they can be administered as an atraumatic restorative treatment (ART). ${ }^{40,44,46,47}$ Incorporation of this approach at an individual and community level as an initial intervention complementing a wider approach including education of the population, minimizing biofilm accumulation, and restricting sugar exposure is recommended. Documented community-based strategies for caries control using occlusal sealants were scarce in LACC except for Costa Rica and Mexico.

\section{Conclusion}

Dental caries occurs due to frequent exposure of the dental biofilm to sugars which, in turn, is also related to the development of other non-communicable diseases that can have a negative impact on the individual's health and quality of life. However, this can easily be avoided through public policies that implement evidence-based strategies to control sugar consumption in an affordable manner and targeting all population groups instead of the most affluent only. Despite widespread use of biofilm control as a regular oral hygiene measure, the prevalence of caries remains high in LACC suggesting the need for strategies that incorporate multiple approaches. Although fluoride has been shown to have anticaries potential in the presence of frequent exposure to sugars, its preventive efficacy could be higher if combined with activities to restrict sugar consumption. Fluoride delivery should 
be extended to the community level using water and salt, although this should also be accompanied by adequate surveillance systems. Regulating the concentration of soluble fluoride (for anticaries effects) in dentifrice formulations is necessary in order to provide the population with an effective strategy for disease control. Although the use of sealants has also been found to be effective in caries control, a thorough understanding of the disease and the role of biofilm accumulation and sugar consumption at the individual level is necessary. It is essential that each Latin American and Caribbean country understands how the various strategies may be implemented or improved at the individual, local, and/or national levels so as to suit their population needs.

\section{Prospects for Latin America}

Better awareness of the association between frequent consumption of sugars and dental caries formation must be developed through widespread dissemination of information in LACC, and strategies to reduce sugar consumption should be encouraged at the individual and community levels. Local and/or national policies should be implemented keeping in mind the sociocultural identity of each Latin American and Caribbean country, and further investment should be made in upstream, integrated population-wide strategies such as taxes on sugary drinks, and stronger regulations on advertising and promotion of sugary foods and drinks targeting children. This will not only help control dental caries incidence but also improve the overall health of the population by preventing other non-communicable diseases such as obesity, diabetes, and cardiovascular diseases.

Although the use of fluoride to control dental caries has contributed to the reduction in prevalence of dental caries in LACC over the years, its use must be monitored at the local, regional and national levels so as to achieve maximum anti-cariogenic effects while also minimizing the risk of dental fluorosis. Moreover, fluoridated water and salt programs, used as a mutually exclusive community level strategy for caries control, should expand their benefits to reach nonrecovered areas of LACC while also simultaneously providing adequate surveillance of the fluoride concentration delivered to the population. Areas with two or more simultaneous sources of fluoride intake should have one of the sources eliminated or reduced.

Although the use of fluoride dentifrices during tooth-brushing is a practice well-embedded in most urban population groups, it should also be promoted as a community level strategy among school children, rural populations, and traditional LACC groups (e.g., indigenous, quilombolas, and riverside Amazonian people) through culturally appropriate and economically sustainable policies and programs. The dentifrice formulations must have optimal levels of soluble fluoride to ensure an anti-caries effect, and the lack of specific legislations regulating the minimum concentration of fluoride in dentifrices in LACC should be addressed. The use of fluoride and occlusal sealants through individual or community level intervention programs should be incorporated into wider strategies addressing sugar consumption and biofilm control. Mouth-rinses, gels, and varnishes can be included as vehicles for fluoride and occlusal sealants in a well-planned program that combines population strategies aiming to shift the distribution of risk factors in the entire population as well as those at the highest risk of disease. Targeting culturally appropriate, economically sustainable caries control interventions to rural populations and native ethnic groups such as indigenous people, quilombolas (African-origin), and riverside Amazonian people remains a crucial challenge.

\section{Acknowledgments}

This paper was prepared for the consensus meeting titled “Dental Caries Prevalence, Prospects and Challenges for LACC", promoted by the Latin American Oral Health Association and Colgate Palmolive Co. with the support of the Federación Odontológica Latinoamericana, Sociedade Brasileira de Pesquisa Odontológica (SBPqO/Brazilian Division of IADR), and the participation of experts from the region, including representatives from national, regional and international dental associations. All participants had the opportunity to review the manuscript and make their own contributions. This paper contributed to the summary and final recommendations of the Dental Caries Regional Consensus. 


\section{References}

1. Fejerskov $O$. Changing paradigms in concepts on dental caries: consequences for oral health care. Caries Res. 2004 May-Jun;38(3):182-91. https://doi.org/10.1159/000077753

2. GBD 2017 Oral Disorders Collaborators. Global, regional, and national levels and trends in Burden of oral conditions from 1990 to 2017: a systematic analysis for the Global Burden of Disease 2017 study. J Dent Res. 2020;99(4):362-373. https://doi.org/10.1177/0022034520908533

3. Paiva SM, Abreu-Placeres N, Camacho MEl, Frias AC, Tello G, Perazzo MF, et al. Dental caries experience and its impact on oral health-related quality of life in Latin American and Caribbean countries. Braz Oral Res. 2021;35(suppl 1):e052. https://doi.org/10.1590/1807-3107bor-2021.vol35.0052

4. Bowen WH, Tenuta LM, Koo H, Cury JA. Dental caries: etiology and pathogenesis. In: Lamont RJ, Hajishengallis GN, Koo H, Jenkinson $H F$, editors. Oral microbiology and immunology. 3rd ed. New York: Wiley \& Sons; 2014. p. 251-65.

5. Martignon S, Roncalli AG, Alvarez E, Aránguiz V, Feldens CA, Buzalaf MAR. Risk factors for dental caries in Latin American and Caribbean countries. Braz Oral Res. 2021;35(suppl 1):053. https://doi.org/10.1590/1807-3107bor-2021.vol35.0053

6. Fejerskov $O$, Larsen MJ. Demineralisation and remineralization: the key to understanding the clinical manifestations of dental caries. In: Fejerskov O, Nyvad B, Kidd E, editors. Dental caries: the disease and its clinical manifestations. 3rd ed. New York: Wiley \& Sons; 2015. pp. 155-70.

7. Whelton HP, Spencer AJ, Do LG, Rugg-Gunn AJ. Fluoride revolution and dental caries: evolution of policies for global use. J Dent Res. 2019 Jul;98(8):837-46. https://doi.org/10.1177/0022034519843495

8. Cury JA, Tenuta LM. Enamel remineralization: controlling the caries disease or treating early caries lesions? Braz Oral Res. 2009;23 Suppl 1:23-30. https://doi.org/10.1590/S1806-83242009000500005

9. Ahovuo-Saloranta A, Forss H, Walsh T, Nordblad A, Mäkelä M, Worthington HV. Pit and fissure sealants for preventing dental decay in permanent teeth. Cochrane Database Syst Rev. 2017;7(7):CD001830. https://doi.org/10.1002/14651858.CD001830.pub5

10. Ouzzani M, Hammady H, Fedorowicz Z, Elmagarmid A. Rayyan-a web and mobile app for systematic reviews. Syst Rev. 2016;5(1):210. https://doi.org/10.1186/s13643-016-0384-4

11. Rodríguez G, Ruiz B, Faleiros S, Vistoso A, Marró ML, Sánchez J, Urzúa I, Cabello R. Probiotic compared with standard milk for high-caries children: a cluster randomized trial. J Dent Res. 2016;95(4):402-7. https://doi.org/10.1177/0022034515623935

12. Mäkinen KK, Bennett CA, Hujoel PP, Isokangas PJ, Isotupa KP, Pape HR Jr, et al. Xylitol chewing gums and caries rates: a 40-month cohort study. J Dent Res. 1995 Dec;74(12):1904-13. https://doi.org/10.1177/00220345950740121501

13. Feldens CA, Vítolo MR, Drachler ML. A randomized trial of the effectiveness of home visits in preventing early childhood caries. Community Dent Oral Epidemiol. 2007 Jun;35(3):215-23. https://doi.org/10.1111/j.1600-0528.2006.00337.x

14. Durán RA, Durán EL, Ojeda GJ, Castellanos WA. [Geographical distribution of fluoride in the public water supply in the province of Tucumán, Argentina]. Salud Colect. 2017 Jan-Mar;13(1):105-22. Spanish. https://doi.org/10.18294/sc.2017.1033

15. Roncalli AG, Noro LR, Cury JA, et al. [Water fluoridation in Brazil: regional distribution and accuracy of information on surveillance in municipalities with more than 50,000 inhabitants]. Cad Saude Publica. 2019;35(6):e00250118. Portuguese. https://doi.org/10.1590/0102-311X00250118

16. Künzel W, Fischer T. Caries prevalence after cessation of water fluoridation in La Salud, Cuba. Caries Res. 2000 Jan-Feb;34(1):20-5. https://doi.org/10.1159/000016565

17. Yévenes I, Zillmann G, Ellicker T, Espinoza P, Xaus G, Cisternas P, et al. Prevalence and Severity of Dental Caries and Fluorosis in 8 Year-old Children With or Without Fluoride Supplementation. Int J Odontostomatol. 2019;13(1):46-50. https://doi.org/10.4067/S0718-381X2019000100046

18. Cury JA, Tenuta LM, Ribeiro CC, Paes Leme AF. The importance of fluoride dentifrices to the current dental caries prevalence in Brazil. Braz Dent J. 2004;15(3):167-74. https://doi.org/10.1590/S0103-64402004000300001

19. Bedos C, Brodeur JM. [Determinants of dental caries in Haitian schoolchildren and implications for public health]. Sante. 2000 May-Jun;10(3):161-8. Portuguese.

20. Marthaler TM. Salt fluoridation and oral health. Acta Med Acad. 2013 Nov;42(2):140-55. https://doi.org/10.5644/ama2006-124.82

21. Betancourt-Lineares A, Irigoyen-Camacho ME, Mejía-González A, Zepeda-Zapeda M, Sánchez-Pérez L. [Dental fluorosis prevalence in Mexican localities of 27 states and the D.F.: six years after the publication of the Salt Fluoridation Mexican Official Regulation]. Rev Invest Clin. 2013 May-Jun;65(3):237-47. Spanish

22. García-Pérez A, Irigoyen-Camacho ME, Borges-Yáñez A. Fluorosis and dental caries in Mexican schoolchildren residing in areas with different water fluoride concentrations and receiving fluoridated salt. Caries Res. 2013;47(4):299-308. https://doi.org/10.1159/000346616

23. Montero M, Rojas-Sanchez F, Socorro M, Torres J, Acevedo AM. [Dental caries and fluorosis in children consuming water with different fluoride concentrations in Maiquetia, Vargas State, Venezuela]. Invest Clin. 2007 Mar;48(1):5-19. Spanish. 
- Community interventions and strategies for caries control in Latin American and Caribbean countries

24. Walsh KI, Cury JA. Fluoride concentrations in salt marketed in Managua, Nicaragua. Braz Oral Res. 2018;32:e45. https://doi.org/10.1590/1807-3107bor-2018.vol32.0045

25. Cury JA, Walsh KI, Vieira W, Ricaldi J. Fluoride concentration in Peruvian salts and the standardization of analysis with specific electrode by the direct method. Braz J Oral Sci. 2018 Jun;17:e18486. https://doi.org/10.20396/bjos.v17i0.8652655

26. Gillespie GM, Baez R. Development of salt fluoridation in the Americas. Schweiz Monatsschr Zahnmed. 2005;115(8):663-9.

27. Fabruccini A, Alves LS, Alvarez L, Alvarez R, Susin C, Maltz M. Comparative effectiveness of water and salt community-based fluoridation methods in preventing dental caries among schoolchildren. Community Dent Oral Epidemiol. 2016 Dec;44(6):577-85. https://doi.org/10.1111/cdoe.12251

28. García Melián M, Sosa M, Cuéllar L, Rodríguez L, Cangas Rancaño R. Sistema de vigilancia de fluoruro en aguas de consumo en Cuba. Rev Cuba Hig Epidemiol. 2002;40(2):136-42.

29. Agudelo-Suárez AA, Martínez-Flórez LM, Madrid-Gutiérrez LM, Vivares-Builes AM, Rocha-Buelvas A. Panorama de la fluorosis dental en Colombia: una revisión exploratoria de la literatura. Univ Odontol. 2013;32(68):133-45.

30. Vallejos-Ragas R, Tineo-Tueros P. Administración de fluoruros en salud pública en el Perú: debilidades y obstáculos. Rev Estomatol Hered. 2015;25(1):79-84. https://doi.org/10.20453/reh.v25i1.2330

31. Conde NC, Rebelo MA, Cury JA. Evaluation of the fluoride stability of dentifrices sold in Manaus, AM, Brazil. Pesqui Odontol Bras. 2003 Jul-Sep;17(3):247-53. https://doi.org/10.1590/S1517-74912003000300009

32. Fernández CE, Carrera CA, Muñoz-Sandoval C, Cury JA, Giacaman RA. Stability of chemically available fluoride in Chilean toothpastes. Int J Paediatr Dent. 2017 Nov;27(6):496-505. https://doi.org/10.1111/ipd.12288

33. Chávez BA, Vergel GB, Cáceres CP, Perazzo MF, Vieira-Andrade RG, Cury JA. Fluoride content in children's dentifrices marketed in Lima, Peru. Braz Oral Res. 2019;33:e051. https://doi.org/10.1590/1807-3107bor-2019.vol33.0051

34. Loureiro LA, Fager AF, Santos Moreira MJ, Maltz M, Hashizume LN. Fluoride Availability and Stability in Children's Toothpastes in Uruguay. J Dent Child (Chic). 2017 May;84(2):52-7.

35. Iwakura ML, Morita MC. [Fluoride mouth-rinsing to prevent dental caries in a Brazilian municipality with fluoridated drinking water]. Rev Panam Salud Publica. 2004 Apr;15(4):256-61. Portuguese. https://doi.org/10.1590/S1020-49892004000400006

36. Arruda AO, Senthamarai Kannan R, Inglehart MR, Rezende CT, Sohn W. Effect of $5 \%$ fluoride varnish application on caries among school children in rural Brazil: a randomized controlled trial. Community Dent Oral Epidemiol. 2012 Jun;40(3):267-76. https://doi.org/10.1111/j.1600-0528.2011.00656.x

37. Palacio R, Shen J, Vale L, Vernazza CR. Assessing the cost-effectiveness of a fluoride varnish programme in Chile: the use of a decision analytic model in dentistry. Community Dent Oral Epidemiol. 2019 Jun;47(3):217-24. https://doi.org/10.1111/cdoe.12447

38. Abreu-Placeres N, Garrido LE, Castillo Jáquez I, Féliz-Matos LE. Does applying fluoride varnish every three months better prevent caries lesions in erupting first permanent molars? A randomised clinical trial. Oral Health Prev Dent. 2019;17(6):541-6. https://doi.org/10.3290/i.ohpd.a43566

39. Dabiri D, Fontana M, Kapila Y, Eckert G, Sokal-Gutierrez K. Community-based assessment and intervention for early childhood caries in rural El Salvador. Int Dent J. 2016 Aug;66(4):221-8. https://doi.org/10.1111/idj.12228

40. Goldman A, Leal SC, Amorim RG, Frencken JE. Treating High-Caries Risk Occlusal surfaces in first permanent molars through sealants and supervised toothbrushing: a 3-year cost-effective analysis. Caries Res. 2017;51(5):489-99. https://doi.org/10.1159/000477822

41. Espinoza-Espinoza G, Corsini G, Rojas R, Mariño R, Zaror C. The cost-utility of school-based first permanent molar sealants programs: a Markov model. BMC Oral Health. 2019;19(1):293. https://doi.org/10.1186/s12903-019-0990-3

42. McCune RJ, Bojanini J, Abodeely RA. Effectiveness of a pit and fissure sealant in the prevention of caries: three-year clinical results. J Am Dent Assoc. 1979 Oct;99(4):619-23. https://doi.org/10.14219/jada.archive.1979.0344

43. Ulate Jiménez J, Montero Salazar O. Prevalencia de sellantes de fosas y fisuras en niños y niñas de 12 años de edad en Costa Rica, 2006. Odovtos - International. J Dent Sci. 2007;(9):50-5.

44. Luengas-Quintero E, Frencken JE, Muñúzuri-Hernández JA, Mulder J. The atraumatic restorative treatment (ART) strategy in Mexico: two-years follow up of ART sealants and restorations. BMC Oral Health. 2013;13:42. Published 2013 Sep 8. https://doi.org/10.1186/1472-6831-13-42

45. Soto-Rojas AE, Escoffié-Ramírez M, Pérez-Ferrera G, Guido JA, Mantilla-Rodriguez AA, Martinez-Mier EA. Retention of dental sealants placed on sound teeth and incipient caries lesions as part of a service-learning programme in rural areas in Mexico. Int J Paediatr Dent. 2012 Nov;22(6):451-8. https://doi.org/10.1111/j.1365-263X.2011.01216.x

46. Pachas Barrionuevo FM, Carrasco Loyola MB, Sánchez Huamán YD. Evaluación de la sobrevida de sellantes ART después de dos años. Rev Estomatol Hered. 2009;19(1):5-11. https://doi.org/10.20453/reh.v19i1.1809

47. Fox M, Navas Perozo R, Zambrano O. Tratamiento de restauración atraumática (ART): una alternativa para el abordaje de comunidades vulnerables en estudios epidemiológicos. Cien Odontol. 2012;9(1):17-24.

48. Sampaio FC, Bönecker M, Paiva SM, Martignon S, Ricomini Filho AP, Pozos-Guillen A, et al. Dental caries prevalence, prospects, and challenges for Latin America and Caribbean countries: a summary and final recommendations from a Regional Consensus. Braz Oral Res. 2021;35(suppl 1):e056. https://doi.org/10.1590/1807-3107bor-2021.vol35.0056 
49. Sheiham A, James WP. Diet and dental caries: the pivotal role of free sugars reemphasized. J Dent Res. 2015 Oct;94(10):1341-7. https://doi.org/10.1177/0022034515590377

50. World Health Organization. Guideline: sugars intake for adults and children. Geneva: World Health Organization; 2015 [cited 2020 Aug 9]. Available froM: http://who.int/nutrition/publications/guidelines/sugars_intake/en

51. Giacaman RA. Sugars and beyond. The role of sugars and the other nutrients and their potential impact on caries. Oral Dis. 2018 Oct;24(7):1185-97. https://doi.org/10.1111/odi.12778

52. Riley P, Moore D, Ahmed F, Sharif MO, Worthington HV. Xylitol-containing products for preventing dental caries in children and adults. Cochrane Database Syst Rev. 2015 Mar;(3):CD010743. https://doi.org/10.1002/14651858.CD010743.pub2

53. Cury JA, Tenuta LM. Evidence-based recommendation on toothpaste use. Braz Oral Res. 2014;28(Spec No):1-7. https://doi.org/10.1590/S1806-83242014.50000001

54. Bergallo P, Castagnari V, Fernández A, Mejía R. Regulatory initiatives to reduce sugar-sweetened beverages (SSBs) in Latin America. PLoS One. 2018;13(10):e0205694. https://doi.org/10.1371/journal.pone.0205694

55. Taillie LS, Reyes M, Colchero MA, Popkin B, Corvalán C. An evaluation of Chile's law of food labeling and advertising on sugar-sweetened beverage purchases from 2015 to 2017: a before-and-after study. PLoS Med. 2020;17(2):e1003015. https://doi.org/10.1371/journal.pmed.1003015.

56. Watt RG, Daly B, Allison P, Macpherson LM, Venturelli R, Listl S, et al. Ending the neglect of global oral health: time for radical action. Lancet. 2019 Jul;394(10194):261-72. https://doi.org/10.1016/S0140-6736(19)31133-X

57. Pan American Health Organization. Proposed 10-year regional plan on oral health for the Americas. Washington, DC: World Health Organization; 2006 [cited 2020 Aug 14]. (Document CD47/14). Available from: https://wwwl.paho.org/english/gov/cd/CD47-14-e.pdf

58. Cury JA, Ricomini-Filho AP, Berti FL, Tabchoury CP. Systemic effects (risks) of water fluoridation. Braz Dent J. 2019;30(5):421-8. https://doi.org/10.1590/0103-6440201903124

59. Walsh T, Worthington HV, Glenny AM, Marinho VC, Jeroncic A. Fluoride toothpastes of different concentrations for preventing dental caries. Cochrane Database Syst Rev. 2019;3(3):CD007868. https://doi.org/10.1002/14651858.CD007868.pub3

60. Van der Weijden FA, Slot DE. Efficacy of homecare regimens for mechanical plaque removal in managing gingivitis a meta review. $J$ Clin Periodontol. 2015 Apr;42 Suppl 16:S77-91. https://doi.org/10.1111/icpe.12359

61. Cury JA, Bandeira Miranda LF, Caldarelli PG, Tabchoury CPM. Dentifrícios fluoretados e o SUS-Brasil: o que precisa ser mudado? Tempus, Actas de Saúde Colet. 2020;14(1):9-27. https://doi.org/10.18569/tempus.v14i1.2631

62. Cury JA, Caldarelli PG, Tenuta LM. Necessity to review the Brazilian regulation about fluoride toothpastes. Rev Saude Publica. 2015;49:74. https://doi.org/10.1590/S0034-8910.2015049005768

63. Marinho VC, Higgins JP, Sheiham A, Logan S. Fluoride toothpastes for preventing dental caries in children and adolescents. Cochrane Database Syst Rev. 2003;(1):CD002278. https://doi.org/10.1002/14651858.CD002278

64. Santos AP, Nadanovsky P, Oliveira BH. A systematic review and meta-analysis of the effects of fluoride toothpastes on the prevention of dental caries in the primary dentition of preschool children. Community Dent Oral Epidemiol. 2013 Feb;41(1):1-12. https://doi.org/10.1111/j.1600-0528.2012.00708.x

65. Marinho VC, Chong LY, Worthington HV, Walsh T. Fluoride mouthrinses for preventing dental caries in children and adolescents. Cochrane Database Syst Rev. 2016 Jul;7(7):CD002284. https://doi.org/10.1002/14651858.CD002284.pub2

66. Pozos-Guillén A, Molina G, Soviero V, Arthur RA, Chavarria-Bolaños D, Acevedo AM. Management of dental caries lesions in Latin American and Caribbean countries. Braz Oral Res. 2021;35(suppl 1):e055. https://doi.org/10.1590/1807-3107bor-2021.vol 